\title{
Manifesting heterozygosity in sex-linked spastic paraplegia?
}

\author{
ID YOUNG, IF PYE, JR MOORE \\ From the Departments of Child Health and Neurology, Leicester Royal Infirmary, Leicester, UK
}

SUMMARY An unusual form of hereditary spastic paraplegia is described. Affected females have a late-onset slowly progressive spastic paraparesis. Affected males show oligophrenia with a rapidly progressive spastic quadriplegia. The mode of inheritance is consistent with sex-linkage, with partial manifestation in female carriers.

Hereditary spastic paraplegia is both clinically and genetically heterogeneous, a point which was recognised over 40 years ago, ${ }^{1}$ and which has been the subject of a recent comprehensive review. ${ }^{2}$ Occasionally a family is encountered which poses a difficult nosological problem for both neurologist and geneticist. Such a family is now reported.

\section{Case histories}

The family pedigree is shown in the figure. There is no known consanguinity in the kindred.

\section{(A) Affected males}

Case 1 (IV 1) The four-year-old proband was born at term following an uneventful pregnancy. All developmental milestones were delayed: at 25 months he scored at the 15 month level on the Bayley Mental Scale. Recent examination revealed marked generalised hyperreflexia, extensor plantar responses, very stiff lower limbs and an alternating convergent strabismus. Investigations giving normal results included: routine haematology and biochemistry, liver function tests, uric acid, creatine kinase, thyroid function, serum aminoacids, banded karyotype, synacthen test, skull and spinal radiography, cerebral CT scan and audiology. No vacuolated lymphocytes were seen.

Case 2 (III 5) Hypertonia and developmental delay were first noted in this 18-year-old boy at six months. He crawled at three years and was briefly able to walk a few steps with support at seven years. Bladder control was achieved at four years and lost at 12 years. Intelligence assessments at eight, 11 and 13 years each yielded an IQ of approximately 50 with no evidence of intellectual deterio-

Address for reprint requests: Dr ID Young, Department of Child Health, Leicester Royal Infirmary, PO Box 65, Leicester LE2 7LX, UK.

Received 3 June 1983 and in revised form 30 September 1983. Accepted 8 October 1983 ration. Vision was normal. On examination he showed severe spastic quadriplegia with clonus and contractures in all limbs, slurred speech, a divergent strabismus with unequal pupils which react to light, and bilateral pale optic discs with no nystagmus. Chromosomes, synacthen test, skull and spine radiography and brain scan are normal.

Case 3 (III 3) This 17-year-old boy lives in the USA. He was diagnosed as having "mild cerebral palsy" at 10 months. At 6 years he could walk with assistance and was toilet trained; these skills were lost by 13 years. At present he requires total care. Photographs suggest a spastic quadriplegia.

(B) Affected females

Case 4 (I 2) This lady tended to trip easily in her late teens, but could walk unassisted until aged thirty-five years when examination showed bilateral optic atrophy, slurred speech, spastic paraparesis and bilateral pes cavus. She became wheelchair bound at 45 years when urinary diversion was performed because of incontinence. Vision, hearing, speech, intellect and manual dexterity were normal up to the time of death, due to pneumonia, at age 49 years; no necropsy was performed.

Case 5 (II 1) This 43-year-old lady walked on her toes in childhood. At 21 years slowly progressive stiffness was treated by bilateral Achilles tendon release operations. At present she can walk only with a stick and has urgency of micturition with occasional incontinence. Vision, hearing and intellect are normal. Examination shows a gross spastic paraparesis with adductor spasm in the lower limbs, marked wasting below the knees and bilateral pes cavus with clawed toes. Sensation is intact. There is slight temporal pallor of the optic discs. Normal investigations include full blood count, routine biochemistry, serum B12 and folate, WR and visually evoked responses. Nerve conduction studies show slowing of motor conduction in the arm and leg with prolonged F-wave latencies in the arm. Sensory conduction is also slow in the arm with low amplitude sensory nerve action potentials: the sural nerve action potential is absent. 


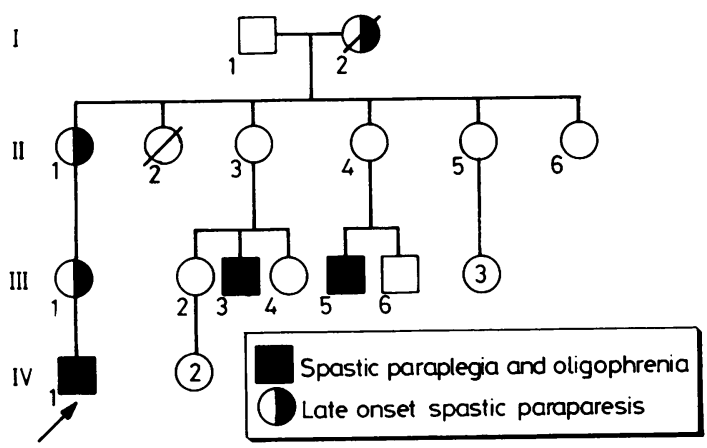

Fig The family pedigree.

Case 6 (III 1) Apart from occasional aching in her left leg this 25-year-old lady is asymptomatic. Examination reveals mildly increased tone in both lower limbs with very brisk tendon reflexes. Sensation and cranial nerve examination are normal.

Individuals I 1, II 4, II 5, II 6 and III 6 have been examined and found to be normal, although II 4 has a long history of severe depressive illness. Correspondence with II 3 , who is aged 40 years and lives in the USA indicates that she is asymptomatic. II 2 died at age 9 months of pneumonia.

Linkage studies for colour vision and the $\mathrm{Xg}^{\mathrm{a}}$ blood group were not informative.

\section{Discussion}

The presence of progressive spasticity in affected members offers a useful starting point in attempting to explain the remarkable constellation of neurological disease within this family. Hereditary spastic paraplegia can be divided arbitrarily into "pure" and "complicated". In the pure forms clinical abnormalities are limited to spasticity and hyperreflexia. Autosomal dominant, ${ }^{3}$ autosomal recessive $^{4}$ and sex-linked recessive inheritance ${ }^{5}$ have been described.

In the family now reported, the oligophrenia in affected boys and the electrophysiological results in case 5 indicate that the disease process is not limited to the cortico-spinal tracts and that their disorder cannot be classified as "pure". The "complicated" forms of hereditary spastic paraplegia include the association of spasticity and hyperreflexia with retinitis pigmentosa, ${ }^{6}$ optic atrophy and dementia, mental retardation ${ }^{8}$ and muscle wasting. ${ }^{9-12}$ Spastic paraparesis may also occur in adrenoleukodystrophy ${ }^{13}$ and adrenoleukomyeloneuropathy, ${ }^{14}$ in both of which there is an abnormality of long chain fatty acid metabolism. On the basis of clinical and investigative findings the condition in this family cannot be readily assigned to any of these forms of hereditary spastic paraplegia.

The pattern of familial involvement in this kindred is also unusual. Autosomal dominant inheritance with variable expressivity and reduced penetrance, both of which are well documented in hereditary spastic paraplegia, ${ }^{1516}$ is possible but unproven in the absence of male to male transmission. Equally possible is sex-linkage with manifesting heterozygosity, although review of published reports of sex-linked hereditary spastic paraplegia, as summarised in the table, fails to reveal any family with an identical condition. In order to prove sexlinkage it is necessary to establish linkage with a known $\mathrm{X}$ chromosome marker, such as colour vision or the $\mathrm{Xg}^{\mathrm{a}}$ blood group, or alternatively demonstrate mosaicism for the basic defect in carrier females. The former has proved unhelpful in this family and the latter is impossible since the basic defect is unknown.

It is concluded that this family harbours an

Table Published reports of sex-linked paraplegia

\begin{tabular}{|c|c|c|c|c|}
\hline Reference & Age of onset & Progression & $I Q$ & Other features \\
\hline $\begin{array}{l}\text { Blumel et al } 1957(17) \\
\text { Johnston and McKusick } 1962(18) \\
\text { Thurmon and Walker } 1971 \text { (19) } \\
\text { Ginter et al } 1974(20)\end{array}$ & $\begin{array}{l}\text { Infancy } \\
\text { Early childhood }\end{array}$ & $\stackrel{?}{\text { Slow }}$ & $\mathfrak{j}^{\text {Normal }}$ & $\begin{array}{l}\text { Nystagmus } \\
\text { Nystagmus } \\
\text { Optic atrophy } \\
\text { Spinocerebeliar } \\
\text { degeneration }\end{array}$ \\
\hline Baar and Gabriel 1966 (21) & Congenital & Rapid & $\downarrow \downarrow$ & $\begin{array}{l}\text { Athetosis } \\
\text { Cerebellar signs }\end{array}$ \\
\hline $\begin{array}{l}\text { Thurmon and Walker } 1971 \\
\text { (kindred 2) (19) }\end{array}$ & $\begin{array}{l}\text { Childhood or } \\
\text { adolescence }\end{array}$ & Slow & Normal & - \\
\hline $\begin{array}{l}\text { Raggio et al }{ }^{*} 1973(22) \\
\text { Zatz et al } 1976(5) \\
\text { Galassi et al } 1977(23)\end{array}$ & $\begin{array}{l}\text { Childhood } \\
\text { Adolescence } \\
\text { Childhood }\end{array}$ & $\begin{array}{l}\text { Very slow? static } \\
\text { Very slow } \\
\text { Slow }\end{array}$ & $\begin{array}{l}\text { Normal } \\
\text { Normal } \\
\downarrow\end{array}$ & $\begin{array}{l}\overline{-} \\
\bar{N} \text { atragmus and optic } \\
\text { atrophy }\end{array}$ \\
\hline
\end{tabular}

*Inheritance was reported as sex-linked but the family pedigree shows one instance of male to male transmission which if correct excludes sex-linkage. 
unusual, if not unique, form of "complicated" hereditary spastic paraplegia with pronounced differences in expression between the sexes and a mode of inheritance consistent with either sexlimited autosomal dominance or sex-linkage with manifesting heterozygosity.

The authors thank the family for their co-operation, Dr Ruth Sanger and the staff of the MRC Blood Group Unit for $\mathrm{Xg}^{\mathrm{a}}$ blood group analyses and Mrs Susan Kenney for typing the manuscript.

\section{References}

' Bell J, Carmichael EA. On hereditary ataxia and spastic paraplegia. Treasury Hum Inherit Vol IV, Part III 1939;141-281.

${ }^{2}$ Baraitser M. The Genetics of Neurological Disorders. Oxford: Oxford University Press, 1982;200-10.

${ }^{3}$ Harding AE. Hereditary "pure" spastic paraplegia: a clinical and genetic study of 22 families. J Neurol Neurosurg Psychiatry 1981;44:871-83.

${ }^{4}$ Vernea J, Symington GR. The late form of pure familial spastic paraplegia. Proc Aust Assoc Neurol 1977; 14:37-41.

5 Zatz M, Penha-Serrano C, Otto PA. X-linked recessive type of pure spastic paraplegia in a large pedigree: absence of detectable linkage with $\mathrm{Xg}$. J Med Genet 1976;13:217-22.

- Gordon AM, Capute AJ, Konigsmark BW. Progressive quadriparesis, mental retardation, retinitis pigmentosa and hearing loss-report of two sibs. Johns Hopkins Med J 1976;138:142-5.

7 Rothner AD, Yahr F, Yahr MD. Familial spastic paraparesis, optic atrophy and dementia. Clinical observations of affected kindred. NY State J Med 1976; 76: 756-8.

${ }^{8}$ Allport RB. Mental retardation and spastic paraparesis in four of eight siblings. Lancet 1971;2:1089.

${ }^{9}$ Neuhauser G, Wiffler C, Opitz JM. Familial spastic paraplegia with distal muscle wasting in the Old Order Amish; atypical Troyer syndrome or "new" syndrome. Clin Genet 1976;9:315-23.
${ }^{10}$ Cross HE, McKusick VA. The Troyer syndrome. A recessive form of spastic paraplegia with distal muscle wasting. Arch Neurol 1967;16:473-85.

" Dyck PJ, Lambert EH. Lower motor and primary sensory neuron diseases with peroneal muscular atrophy. II Neurologic, genetic and electrophysiologic findings in various neuronal degenerations. Arch Neurol 1968;18:619-25.

12 Garland HG, Astley CE. Hereditary spastic paraplegia with amyotrophy and pes cavus. J Neurol Neurosurg Psychiatry 1950;13:130-3.

${ }^{13}$ O' Neill BP, Moser HW, Saxena KM. Familial X-linked Addison disease as an expression of adrenoleukodystrophy (ALD): elevated C26 fatty acid in cultured skin fibroblasts. Neurology (NY) 1982;32:543-7.

${ }^{14}$ O'Neill BP, Marmion LC, Feringa ER. The adrenoleukomyeloneuropathy complex: expression in four generations. Neurology (NY) 1981;31:151-6.

is Bone I, Johnson RH, Ferguson-Smith MA. Occurrence of familial spastic paraplegia in only one of monozygous twins. J Neurol Neurosurg Psychiatry 1976; 39:1129-33.

${ }^{16}$ Burdick AB, Owens LA, Peterson CR. Slowly progressive autosomal dominant spastic paraplegia with late onset, variable expression and reduced penetrance: a basis for diagnosis and counselling. Clin Genet 1981;19:1-7.

${ }^{17}$ Blumel J, Burke Evans E, Eggers GWN. Hereditary cerebral palsy. A preliminary report. J Pediatr 1957;50:454-8.

18 Johnston AW, McKusick VA. A sex-linked recessive form of spastic paraplegia. Am J Hum Genet 1962;14:83-94.

19 Thurmon TF, Walker BA, Scott CI, Abbott MH. Two kindreds with a sex-linked recessive form of spastic paraplegia. Birth Defects Orginal Article Series 1971;7:219-21.

${ }^{20}$ Ginter DN, Konigsmark BA, Abbott MH. X-linked spinocerebellar degeneration. Birth Defects Original Article Series 1974;10:334-6.

${ }^{21}$ Baar HS, Gabriel AM. Sex-linked spastic paraplegia. Am J Ment Def 1966;71:13-18.

${ }^{22}$ Raggio JF, Thurmon TF, Anderson EE. X-linked hereditary spastic paraplegia. J La State Med Soc 1973;125:4-6.

${ }^{23}$ Galassi G, Penne A, Colombo A, Forabosco A. Paraplegia spastica complicata ad eredità legata al sesso. Acta Neurol 1977;32:746-56. 